\title{
Rosanna Gorris Camos, Dans le labyrinthe de Gohory, lecteur et traducteur de Machiavel
}

\section{Dario Cecchetti}

\section{(2) OpenEdition}

1 Journals

\section{Edizione digitale}

URL: http://journals.openedition.org/studifrancesi/7517

DOI: $10.4000 /$ studifrancesi. 7517

ISSN: 2421-5856

\section{Editore}

Rosenberg \& Sellier

\section{Edizione cartacea}

Data di pubblicazione: 1 décembre 2009

Paginazione: 611

ISSN: 0039-2944

\section{Notizia bibliografica digitale}

Dario Cecchetti, «Rosanna Gorris Camos, Dans le labyrinthe de Gohory, lecteur et traducteur de

Machiavel», Studi Francesi [Online], 159 (LIII | III) | 2009, online dal 30 novembre 2015, consultato il 09 janvier 2021. URL: http://journals.openedition.org/studifrancesi/7517 ; DOI: https://doi.org/10.4000/ studifrancesi.7517

Questo documento è stato generato automaticamente il 9 janvier 2021.

\section{(c) (1)}

Studi Francesi è distribuita con Licenza Creative Commons Attribuzione - Non commerciale - Non opere derivate 4.0 Internazionale. 


\title{
Rosanna Gorris Camos, Dans le labyrinthe de Gohory, lecteur et traducteur de Machiavel
}

\author{
Dario Cecchetti
}

\section{NOTIZIA}

ROSANNA GORRIS CAMOS, Dans le labyrinthe de Gohory, lecteur et traducteur de Machiavel, «Laboratoire Italien», 8, 2008, pp. 195-229.

1 L'A. offre agli studiosi - come sempre nei suoi densi lavori - un ricchissimo materiale documentario e bibliografico. In questo caso ricostruisce l'ambiente del cosiddetto cenacolo d'Issy, riunito intorno a Jacques Gohory, che a partire dal 1544 si interessò all'opera di Machiavelli, di cui tradusse i Discorsi sopra la prima deca di Tito Livio (1544 e 1548) e il Principe (1571). Nel presente studio vengono ricostruite la rete complessa di mediazioni che fanno da veicolo alla diffusione e alla fortuna di Machiavelli in Francia e le strategie editoriali che presiedono a tale fortuna, con particolare riguardo a quegli anni quaranta del Cinquecento, cruciali per l'affermazione in Francia di un machiavellismo (e anti-machiavellismo). La traduzione di Machiavelli, iniziata da Gohory nel 1544 su istigazione di Milles Perrot nell'entourage dei Montmorency, alimenta le nostalgie politiche di tutto un gruppo di intellettuali che si riconosce nei testi machiavelliani (Gohory, Perrot, La Planche, Vintimille, Cappel), gruppo che viene dottamente rievocato nel saggio di Rosanna Gorris Camos. 